\title{
Influence of Watering Frequency on Forage Consumption and Steer Performance in Southeastern Kenya
}

\author{
N.K.R. MUSIMBA, REX D. PIEPER, JOE D. WALLACE, AND MICHAEL L. GALYEAN
}

\section{Abstract}

Forty-five zebu steers (avg wt $311 \mathrm{~kg}$ ) were allotted to 3 watering frequency treatments with 15 steers/treatment. The treatments involved watering once every day (1/1), watering once every 2 days $(1 / 2)$ and watering once every 3 days $(1 / 3)$ to investigate the effect of watering frequency on forage consumption and steer performance. Three steers/treatment were used to quantify fecal output and estimated forage consumption. All steers were grazed together in a 100-ha paddock for 10 hours daily and confined in a corral overnight. Steers were allowed ad libitum access to water only in the evenings according to the watering schedule. The study was conducted over 6 months, during which time total fecal collections were made in March, April, June, and July. All steers were weighed approximately every 2 weeks. Forage consumption was reduced $(P<0.01)$ for steers watering $(1 / 2)$ and $(1 / 3)$, compared with the $(1 / 1)$ watered group. Forage intake was highest $(P<0.01)$ in April when herbage was green and growing. Steer performance followed a seasonal pattern reflecting changes in forage quality. Watering frequency did not influence steer performance. Reducing watering frequency from daily to once ever 2 or $\mathbf{3}$ days may enhance utilization of available range and save on cost of providing water for cattle under certain pastoral conditions.

\section{Key Words: intake, cattle weight changes, diet comsumption}

Grazed forage represents the main source of feed for cattle on semiarid and arid rangelands throughout the world. Feed intake is a fundamental aspect of animal nutritional status because it sets the input of nutrients and, hence, is a determining factor of animal function and response. Crampton et al. (1960) and Lippke (1980) observed that animal productivity is the best measure of nutritive value of forage and that intake limits production more than digestibility of forages.

Forage intake can be estimated in a conventional feeding trial that involves pen-feeding harvested forage to confined animals. Pen-feeding using harvested forage, however, does not accurately reflect the forage selected under free-ranging grazing conditions (Arnold 1970, Kartchner and Campbell 1979). Wallace and Van Dyne (1970) observed that intake of pen-fed animals differed from that of animals grazed on dry ranges.

Water and feed consumption are closely related (Winchester and Morris 1956, Phillips 1960), and restricted water intake leads to reduced feed consumption (French 1956, Weeth and Lesperance 1965, Johnson et al. 1966, Moore et al. 1983). Data for the above studies were collected under indoor conditions with animals offered harvested feeds of known moisture content, and may not truly represent practical grazing situations where animals have a choice of selecting plants and plant parts of variable moisture and nutrient content.

This study was designed to test the hypothesis that watering frequency does not influence intake of nutrients and liveweight gain of zebu steers under a rangeland grazing situation typical of Kenya.

Authors are former graduate student and professor, Department of Animal and Range Sciences, New Mexico State University, Las Cruces 88003 . Current address of Musimba is Ministry of Agriculture and Livestock Development, National Range Research Station, P.O. Box 12, Makindu, Kenya.

Journal Article No. 1274 of the New Mexico Agr. Exp. Sta., Las Cruces.

Manuscript accepted 24 April 1987.

\section{Materials and Methods}

The study was conducted at the National Range Research Station Kiboko, Kenya, $164 \mathrm{~km}$ southeast of Nairobi. The area is classified as transition between Acacia/Themeda savanna and Commiphora/Acacia woodland (Pratt et al. 1966). I.ong-term mean annual rainfall averages $600 \mathrm{~mm} /$ year with a bimodal pattern of a minor peak during October through December, and a major peak from March through June. Mean annual temperature averages $23^{\circ} \mathrm{C}$.

A study paddock of 100 ha was established in a grazing block and $10 \times 100-\mathrm{m}$ transects were systematically laid out in the study paddock. Total herbage production was measured by clipping $0.49-\mathrm{m}^{2}$ circular frames systematically placed at $10-\mathrm{m}$ intervals along each transect. The study was conducted from February to July 1984 and included 4 sampling periods: 16-21 March, 20-29 April, 2-9 June, and 14-24 July. Vegetation was characterized by Commiphora spp., Acacia spp. and Balanites aegyptica trees in the upper story with woody shrubs such as Greura spp., Hermania spp. and Lantana virbunoides in the middle layer. Grasses comprising the understory included Digitaria macroblephara, Chloris roxburghiana, Bothriocloa inscupta, Enteropogon macrostachyus, Cymbopogon spp. and Eragrostis spp.

Forty-five intact zebu steers about 3 years old and averaging 311 $\mathrm{kg}$ were selected and allotted to 3 watering frequency treatments: watered once every day $(1 / 1)$, watered once in 2 days $(1 / 2)$, and watered once in 3 days $(1 / 3)$. Within each treatment 3 steers were trained to wear fecal bags for total fecal collection. Feces were collected for 5 consecutive days during each sampling period. Fecal bags were emptied twice daily and the daily fecal output weighed wet, subsampled, oven-dried, and reweighed. Two esophageal fistulated zebu steers were allocated to each watering treatment for sampling grazed forage. Esophageal masticates were collected from steers during 30 -min periods each day for 3 alternate days during each sampling period. Esophageal fistulated steers and intact steers grazed together in the study paddock for 10 hours daily from $0700 \mathrm{~h}$ to $1700 \mathrm{~h}$ and then were confined in the night corral. All steers were allowed to water only in the evenings in accordance with their respective watering frequency treatment.

The $\mathbf{4 5}$ intact study steers were weighed approximately every 2 weeks throughout the study period. Steers were weighed in the mornings after an overnight fast.

\section{Chemical Analyses}

Dry samples of feces and esophageal masticates were analyzed for dry matter and organic matter content (AOAC 1984). Masticate samples were subjected to in vitro dry matter and organic matter digestion by the 2-stage procedure of Tilley and Terry (1963) using inoculum from steers maintained on native grass hay diets. Forage consumption (dry and organic matter) was estimated by dividing fecal output by forage indigestibility (Van Dyne 1968).

Data for intake of nutrients and steer performance were subjected to statistical analyses as a split-plot design, with watering treatment as fixed and sampling period as random variables using steers as the sampling units.

\section{Results and Discussion}

\section{Herbage Standing Crop}

The yield of perennial grasses differed $(P<0.01)$ among sampling 
Table 1. Standing crop of herbage ( $\mathrm{kg} / \mathrm{ha}$ ) during the four sampling periods.

\begin{tabular}{lccccc}
\hline \hline & \multicolumn{4}{c}{ Sampling period } & \\
\cline { 2 - 5 } & March & April & June & July & SE \\
\hline Perennial grasses & $406.5^{\mathrm{a} 2}$ & $466.2^{\mathrm{a}}$ & $271.2^{\mathrm{b}}$ & $280.7^{\mathrm{b}}$ & 67 \\
Annual grasses & $86.5^{\mathrm{a}}$ & $13.1^{\mathrm{b}}$ & $\mathrm{T}^{\mathrm{b}}$ & $\mathrm{T}^{\mathrm{b}}$ & 17 \\
Forbs & 154.7 & 156.3 & 224.9 & 213.2 & 69 \\
Total herbage & 647.7 & 635.6 & 496.1 & 493.9 & 83 \\
\hline
\end{tabular}

${ }^{185}$ Pooled standard error of the mean, $n=10$.

${ }_{3 \mathrm{~T}}^{2 \mathrm{~b}}$ Row means with different superscripts differ $(P<0.01)$.

${ }^{3 T}$ Trace.

periods, being highest at the beginning of the study and after the rains in April (Table 1). Annual grasses declined $(P<0.01)$ after the first sampling in March and occurred only in trace amounts in June and July. Forbs and small shrub biomass components did not differ $(P>0.01)$ among periods. Total herbage decreased from 648 to $494 \mathrm{~kg} / \mathrm{ha}$ by the end of the study, which could be mainly attributed to below-average precipitation in March and April. Herbage availability, however, was never low enough to influence forage intake by steers (Handl and Rittenhouse 1972). The decline in herbage weight was probably related to consumption by the cattle, other herbivores, and physical losses.

\section{Nutrient Intake}

Dry matter intake did not change $(P>0.01)$ among the various sampling periods, although it ranged from 1.60 to $1.73 \%$ of body weight (Table 2). Intake was highest in April when forage was

Table 2. Daily intake of dry matter (DM), digestible organic matter (DOM), neutral detergent flber (NDF) and crude protein (CP) during the four sampling periods averaged over watering treatments.

\begin{tabular}{|c|c|c|c|c|c|}
\hline \multirow[b]{2}{*}{ Item } & \multicolumn{4}{|c|}{ Sampling period } & \multirow[b]{2}{*}{$\mathbf{S E}^{1}$} \\
\hline & $\begin{array}{c}\text { March } \\
16-25\end{array}$ & $\begin{array}{c}\text { April } \\
20-29\end{array}$ & $\begin{array}{l}\text { June } \\
2-11\end{array}$ & $\begin{array}{c}\text { July } \\
14-24\end{array}$ & \\
\hline & \multicolumn{5}{|c|}{$\%$ of body weight } \\
\hline DM intake/day & 1.65 & 1.73 & 1.63 & 1.60 & 0.07 \\
\hline DOM intake/day & $0.85^{n 2}$ & $1.03^{b}$ & $0.89^{c}$ & $0.77^{\mathrm{d}}$ & 0.04 \\
\hline NDF intake/day & $1.09^{\circ}$ & $1.03^{\mathrm{b}}$ & $1.08^{\mathrm{a}}$ & $1.15^{\mathrm{a}}$ & 0.05 \\
\hline CP intake (g/day) & $581^{\star}$ & $716^{\mathrm{b}}$ & $399^{\mathrm{c}}$ & $329^{d}$ & 21.7 \\
\hline
\end{tabular}

ISE = Standard error of means $(n=9)$.

Row means with different superscripts differ $(P<0.01)$

growing and lowest in July when forage was dormant. Intake of DOM increased $(P<0.01)$ from March to April when forage was growing and decreased $(P<0.01)$ as forage became mature in June. Intake showed further decline in July when forage was entering dormancy. These intake patterns agree with published data regarding availability of nutrients and stage of forage maturity. Young growing forages with high leaf:stem ratios tend to be more digestible than more mature forages. Increased intake of growing forages is usually associated with low cell wall content, rapid rate of fermentation (Smith et al. 1971), and subsequent faster rate of passage (Osbourn et al. 1974). Similar trends in forage intake by grazing cattle have been reported with zebu cattle in Rhodesia (Elliot and Fokkema 1961), and with temperate cattle breeds in New Mexico (McCollum and Galyean 1985) where estimated intake was highest during the growing stage and declined as forage advanced to maturity.

Neutral detergent fiber intake was lowest $(P<0.01)$ when forage was growing, and increased $(P<0.01)$ as forage advanced in maturity, reflecting changes in chemical composition of the forage. Neutral detergent fiber intake accounted for $76 \%$ of the variation in dry matter intake. This agrees with the view held by Ellis (1978) that intake of forage by ruminants is limited by physical bulk and the neutral detergent fiber fraction of the feed. Crude protein intake was highest $(P<0.01)$ during the growing stage in April and declined drastically as forage advanced in maturity to early dormancy in July.

\section{Effect of Watering Frequency}

Compared with daily watered steers, intermittent watering reduced $(P<0.01)$ intake of DM, DOM, and NDF for steers watered at $1 / 2$ and $1 / 3$ watering frequencies (Table 3). The decrease in feed intake found in this study confirms findings of

Table 3. Intake of dry matter (DM), digestible organic matter (DOM), crude protein (CP) and neutral detergent that fiber (NDF) as influenced by watering regimen averaged over periods.

\begin{tabular}{lcccc}
\hline \hline & \multicolumn{3}{c}{ Watering regimen } \\
\cline { 2 - 5 } Item & $\begin{array}{c}\text { Once a } \\
\text { day }\end{array}$ & $\begin{array}{c}\text { Once in } \\
\text { 2 days }\end{array}$ & $\begin{array}{c}\text { Once in } \\
3 \text { days }\end{array}$ & SE \\
\hline & & $\%$ of body weight & \\
\hline & $1.84^{\text {a2 }}$ & $1.54^{\mathrm{b}}$ & $1.57^{\mathrm{b}}$ & 0.06 \\
DOM intake/day & $1.06^{\mathrm{a}}$ & $0.84^{\mathrm{b}}$ & $0.78^{\mathrm{b}}$ & 0.03 \\
NDF intake/day & $1.21^{\mathrm{a}}$ & $1.02^{\mathrm{b}}$ & $1.02^{\mathrm{b}}$ & 0.04 \\
CP intake (g/day) & $534^{\mathrm{d}}$ & $523^{\mathrm{d}}$ & $461^{\circ}$ & 0.17 \\
\hline
\end{tabular}

$1 \mathrm{SE}=$ pooled standard error of mean, $n=9$.

${ }^{2{ }^{2}{ }^{2}}$ Row means with different superscripts differ $(P<0.01)$

${ }^{2 d e f}$ Row means with different superscripts differ $(P<0.05)$

earlier studies in which ruminants were subjected to water restriction (Johnson et al. 1966, Thornton and Yates 1968 and Moore et al. 1983). Crude protein intake decreased $(P<0.01)$ for animals watered 1/3 relative to those watered at the $1 / 1$ and $1 / 2$ watering schedules. Reduction in intake with reduced watering is associated with decreased rate of digesta passage, hence extended retention time of digesta especially in the rumino-reticulum (Phillips 1960 , Musimba et al. 1987).

\section{Steer Performance}

Watering frequency did not affect $(P<0.01)$ average steer growth rate over the whole study period (Table 4, Fig. 1). Steer weights were not significantly different $(P<0.01)$ across watering frequencies although mean steer weights were somewhat variable across

Table 4. Average initial and final steer weights and standard errors for the different frequency of watering treatments.

\begin{tabular}{lccc}
\hline \hline $\begin{array}{l}\text { Frequency of } \\
\text { watering treatments }\end{array}$ & $\begin{array}{c}\text { Initial } \\
\text { wt. } \pm \text { S.E. }\end{array}$ & $\begin{array}{c}\text { Final } \\
\text { wt. } \pm \text { S.E. }\end{array}$ & Weight gain \\
\hline & $308 \pm 4.8$ & $337 \pm 5.5$ & 29 \\
Once a day & $307 \pm 4.7$ & $355 \pm 5.4$ & 30 \\
Once in 2 days & $307 \pm 4.7$ & $337 \pm 5.5$ & 30 \\
Once in 3 days & & & \\
\hline
\end{tabular}

watering frequencies during early stages of the trial (Fig. 1). Steers gained about $30 \mathrm{~kg}$ on all watering frequencies (Table 3). Digestibility was increased by 3 to $6 \%$ at reduced water frequencies (Musimba et al. 1987) and probably acted to maintain comparable body weights. Johnson et al. (1966) also demonstrated that apparent digestibility, or rate of disappearance of nutrients in the digestive tract of cattle, was increased when animals were subjected to restricted drinking.

Steers lost weight in March and July when forage was mature, and gained weight faster in April when forage was growing than in June when forage was in early maturity stage (Fig. 1). The growth pattern shown by steers in the current study, which can be considered a response to changing forage quality, has been reported in studies conducted in temperate and tropical pastures. Romero and Siebert (1980) observed that cattle on native pastures of northern Australia had rapid weight gains for short periods, and frequently lost weight for long periods in response to changes in forage quality. 


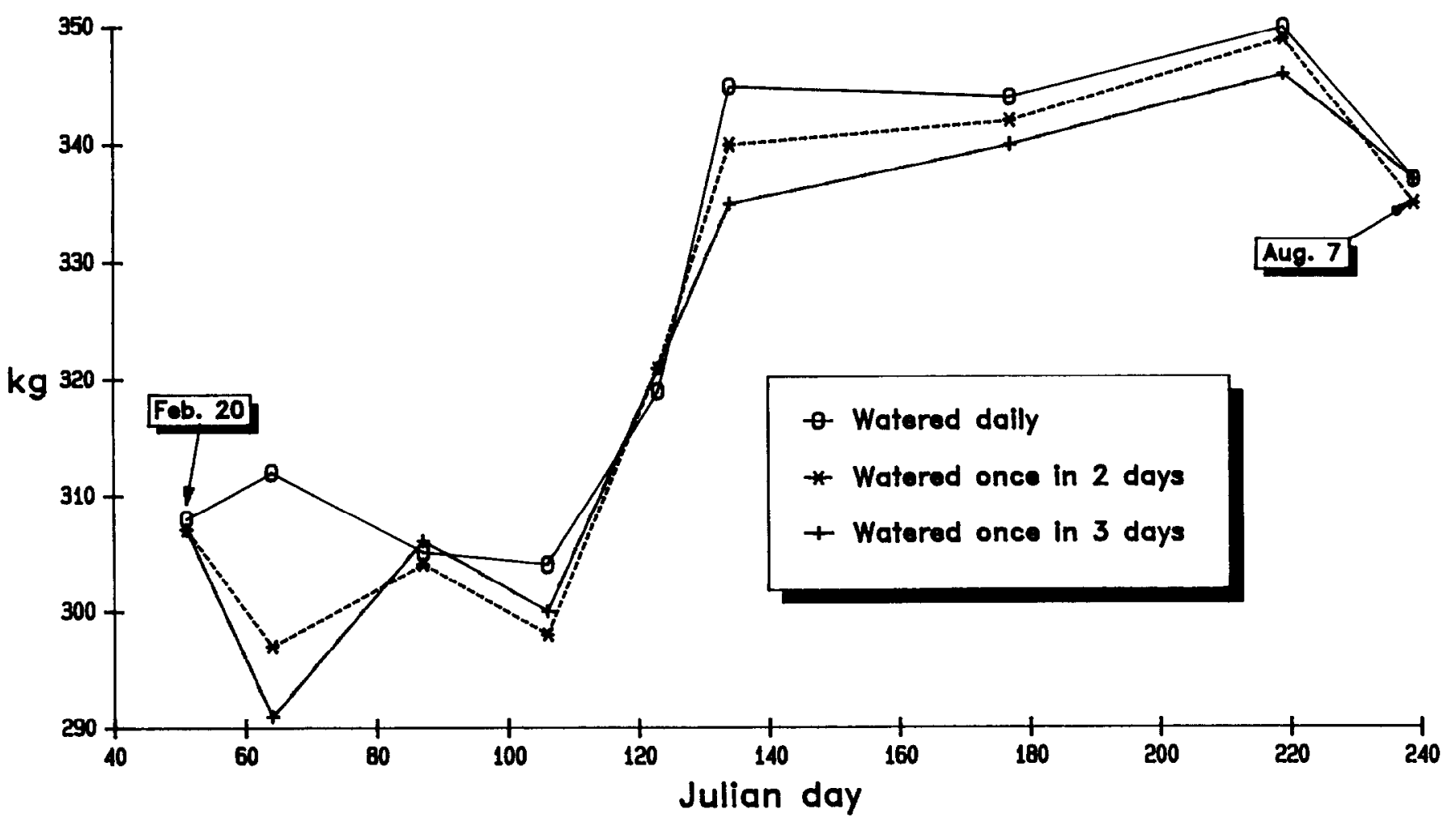

Fig. 1. Average steer weights for the 3 watering regimes during the study period.

\section{Management Implications}

Cordova et al. (1978) showed that average forage intake by cattle is about $1.8 \%$ of body weight, which does not deviate from findings of the current short-term study where dry matter intake ranged from 1.6 to $1.7 \%$ of steer body weight. Such data can be useful for budgeting of forage requirements in areas similar to those where the present study was conducted. Researchers with the International Livestock Centre for Africa (ILCA) have recently initiated a 3-day watering strategy for pastoralists in Ethiopia to reduce the labor cost associated with raising water from underground wells (ILCA 1983). While intermittent watering of animals can be regarded as cost effective, concomitant benefits may be accrued, such as increased efficiency of forage utilization and extended grazing period to cover dry periods due to reduced intake by animals. In addition, better utilization of available range and potentially reduced soil erosion around watering points can be achieved with intermittent watering when animals travel to graze distant pastures from watering points without returning to the watering points on a daily basis. Based on data from the current study, it appears that watering once every 2 or 3 days may be possible for certain classes of cattle.

\section{Literature Cited}

AOAC. 1984. Official methods of analysis (14th Ed.). Association of Official Analytical Chemists. Washington D.C.

Arnold, G.W. 1970. Regulation of food intake in grazing ruminants. In: Physiology of Digestion and Metabolism in the Ruminant. A. T. Phillipson (Ed.). Oriel Press Ltd., New Castle.

Cordova, F.J., J.D. Wallace, and R.D. Pieper. 1978. Forage intake by grazing animals: A review: J. Range Manage. 31:430-438.

Crampton, E.W., E. Donefer, and L.E. Loyd. 1960. A nutritive value index for forages. J. Anim. Sci. 16:538-544.

Elliot, R.C., and K. Fokkema. 1961. Herbage consumption studies on beef cattle. In: Intake Studies on Afrikander and Mashona Cows on Veld Grazing 1958-59. Rhod. Agr. J. 58:49-57.
Ellis, W.C. 1978. Determinants of grazed forage. J. Dairy Sci. 61:1828-1840.

French, M.H. 1956. The importance of water in the management of cattle. E. Afr. Agr. For. J. 21:171-181.

Hand, W.P., and L.R. Rittenhouse. 1972. Herbage yield and intake of grazing steers. Proc. West. Sec. Amer. Soc. Anim. Sci. 23:197-200.

ILCA Annual Report. 1983. Improving Livestock and Crop-Livestock Systems in Africa. International Livestock Centre for Africa; Addis Ababa, Ethiopia.

Johnson, W.L., T.R. Jevier, W.A. Hardison, and A.L. Ordoveza. 1966. The effects of restricted water intake on food intake, digestibility and nitrogen balance with cattle and carabao. Phillipine Agr. 49:668-680.

Kartchner, R.J., and C.M. Campbell. 1979. Intake and digestibility of range forages consumed by livestock. Montana Agr. Exp. Sta. and USDA. SEA-AR Bull. 718.

Lippke, H. 1980. Forage characteristics related to intake, digestibility and gain by ruminants. J. Anim. Sci. 50:952-961.

McCollum, F.T., and M.L. Galyean. 1985. Cattle grazing blue grama rangeland. Il. Seasonal forage intake and digesta kinetics. J. Range Manage. 38:543-546.

Moore, T., B. Howard, and B.D. Siebert. 1983. Effect of level of water intake on water, energy and nitrogen balance and thyroxine secretation in sheep and goats. Austr. J. Agr. Res. 34:441-446.

Musimba, N.K.R., M.L. Galyean, J.L. Holechek, and R.D. Pieper. 1987. Influence of frequency of drinking on particulate passage rate and dry matter disappearance of grazing zebu cattle. J. Range Manage. 40:418421.

Osbourn, D.F., R.A. Terry, G.E. Outen, and S.B. Cammell. 1974. The significance of determination of cell walls as the rational basis for the nutritive evaluation of forages. Proc. XII Int. Grassl. Cong. III.

Phillips, G.D. 1960. The relationship between water and food intakes of European and zebu-type steers. J. Agr. Sci. (Camb.) 54:231-234.

Pratt, D.J., P.J. Greenway, and M.D. Gwyne. 1966. A classification of E. African Rangeland. J. Appl. Ecol. 3:369-382.

Romero, A., and B.D. Siebert. 1980. Seasonal variation of nitrogen and digestible energy intake of cattle on tropical pastures. Austr. J. Agr. Res. 31:393-400.

Smith, L.W., H.K. Goering, D.R. Waldo, and C.H. Gordon. 1971. In vitro digestion rate of forage cell wall components. J. Dairy Sci. 54:71-76. 
Thornton, R.F., and N.G. Yates. 1968. Some effects of water restriction on apparent digestibility and water excretion by cattle. Aust. J. Agr. Res. 19:665-672.

Tilley, J.M.A., and R.A. Terry. 1963. A 2 stage technique for the in vitro digestion of forage crops. J. Brit. Grassl. Soc. 18:104-111.

Van Dyne G.M. 1968. Measuring quantity and quality of the diet of herbivores. In: Practical guide to the study of productivity of large herbivores. F.B. Golley and H.K. Buechner, eds. Blackwell Scientific Pub. Oxford, England.
Wallace, J.D., and G.M. Van Dyne. 1970. Precision of indirect methods of estimating digestibility of forage consumed by grazing cattle. J. Range Manage. 23:424-430.

Weeth, H.J., and A.L. Lesperance. 1965. Intermittent watering of growing beef heifers. Proc. West. Sec. Amer. Soc. Anim. Sci. 16:XIX 1-6.

Winchester, C.F., and M.J. Morris. 1956. Water intake rates of cattle. J. Anim. Sci. 15:722-740. 